\title{
Revision of the Neotropical spider genus Gephyroctenus (Araneae: Ctenidae: Calocteninae)
}

\author{
Daniele Polotow \& Antonio D. Brescovit
}

Laboratório de Artrópodes, Instituto Butantan. Avenida Vital Brazil 1500, 05503-900 São Paulo, São Paulo, Brasil. E-mail: danielepolotow@yahoo.com.br; adbresc@terra.com.br

\begin{abstract}
Gephyroctenus Mello-Leitão, 1936 (type species G. philodromoides Mello-Leitão, 1936) is revised. Three species formerly described in this genus are synonymized with species from other genera: G. kolosvaryi Caporiacco, 1947, with Acanthoctenus spinipes Keyserling, 1877, G. parvus Caporiacco, 1947, with Phymatoctenus comosus Simon, 1897, and G. vachoni Caporiacco, 1955, with Caloctenus gracilitarsis Simon, 1897. Eight new species are described: G. portovelho sp. nov., from the States of Rondônia and Amazonas, Brazil; G. divisor sp. nov. and G. acre sp. nov., from the State of Acre, Brazil; G. atininga sp. nov., G. esteio sp. nov. and G. mapia sp. nov., from the State of Amazonas, Brazil; G. juruti sp. nov., from the Department of Loreto, Peru and the State of Pará, Brazil; G. panguana sp. nov., from the Department of Huanuco, Peru. The genus can be distinguished by the presence of a cymbial retrolateral groove, retrolateral origin of embolus, embolus long and thin, median apophysis with a subdistal hook, and hyaline projection close to the embolus base in the male palp and by the fused median and lateral fields in a single epigynal plate, copulatory opening located dorsally in an atrium, and elongated copulatory ducts surrounding the spermathecae in the female epigynum. Field observations on the hunting behavior on ants in trumpet trees (Cecropia) are provided for two species, G. philodromoides and G. mapia sp. nov.
\end{abstract}

KEY WORDS. Ant; Azteca; Cecropia; taxonomy; trumpet tree.

RESUMO. Revisão do gênero de aranhas neotropicais Gephyroctenus Mello-Leitão (Araneae: Ctenidae: Calocteninae). Gephyroctenus Mello-Leitão, 1936 (espécie-tipo G. philodromoides Mello-Leitão, 1936), é revisado. Três espécies descritas neste gênero são sinonimizadas com espécies de outros gêneros: G. kolosvaryi Caporiacco, 1947, com Acanthoctenus spinipes Keyserling, 1877, G. parvus Caporiacco, 1947, com Phymatoctenus comosus Simon, 1897, e G. vachoni Caporiacco, 1955, com Caloctenus gracilitarsis Simon, 1897. Oito novas espécies são descritas: G. portovelho sp. nov., dos Estados de Rondônia e Amazonas, Brasil; G. divisor sp. nov. e G. acre sp. nov., do Estado do Acre, Brasil; G. atininga sp. nov., G. esteio sp. nov. e G. mapia sp. nov., do Estado do Amazonas, Brasil; G. juruti sp. nov., do Department de Loreto, Peru e Estado do Pará, Brazil; e G. panguana sp. nov., do Department de Huanuco, Peru. Os machos do gênero podem ser distinguidos pela presença de uma fenda retrolateral no címbio, origem retrolateral do êmbolo, êmbolo longo e fino, apófise média com um gancho subdistal e projeção hialina na base do êmbolo no palpo, e as fêmeas podem ser distinguidas pelos campo mediano e campos laterais fundidos em uma única placa, aberturas copulatórias localizadas em um átrio e dutos copulatórios alongados no epígino. Observações de campo sobre o comportamento de caça de formigas em embaúbas (Cecropia) são fornecidas para duas espécies deste gênero, G. philodromoides e G. mapia sp. nov.

PALAVRAS-CHAVE. Azteca; Cecropia; embaúba; formiga; taxonomia.

SIMON (1897) proposed Calocteninae based mainly on the shape of the labium, sternum and carapace, and by a set of numerous and elongated spines on the first and second pairs of legs. Currently, it is composed by five genera: Caloctenus Keyserling, 1877 and Gephyroctenus Mello-Leitão, 1936 from South America, Diallomus Simon, 1897 from Sri Lanka, Apolania Simon, 1897 from Seychelles Islands, and Mahafalytenus Silva, 2007 from Madagascar (Silva 2003, Platnick 2008). The sub- family is characterized by the presence of a set of elongated spines on tibia and metatarsus of the first and second pairs of legs, six thickened and elongated anal setae, and reduced number of cylindrical glands spigots in the posterior median spinnerets (SILVA 2003).

Gephyroctenus was proposed by Mello-LeITão (1936) to include the type species G. philodromoides Mello-Leitão, described based on an immature male collected in Paranaguá, 
State of Paraná, Brazil. The genus was distinguished by the shape of abdomen and a set of elongated ventral spines on the tibia and metatarsus (Mello-Leitão, 1936).

A few years later, Caporiacco $(1947,1955)$ added three species to this genus: Gephyroctenus kolosvaryi Caporiacco, 1947 and G. parvus Caporiacco, 1947 were both described from immature females collected in Guyana and G. vachoni Caporiacco, 1955 was described from an immature female collected in Caracas, Venezuela

In this paper we present a taxonomic revision of Gephyroctenus, including eight new species from South America. Field observations of the foraging behavior are described for two species of this genus.

\section{MATERIAL AND METHODS}

The material examined is deposited in the following institutions (curator in parenthesis): BMNH, The Natural History Museum, London (J. Beccaloni); IBSP, Instituto Butantan, São Paulo (A. D. Brescovit); INPA, Instituto Nacional de Pesquisas da Amazônia, Manaus (A. L. Henriques); MNHN, Muséum National d'Histoire Naturelle, Paris (C. Rollard); MNRJ, Museu Nacional, Universidade Federal do Rio de Janeiro, Rio de Janeiro (A.B. Kury); MPEG, Museu Paraense "Emilio Goeldi", Belém (A. B. Bonaldo); MUCV, Museo de Biología, Facultad de Ciencias, Universidad Central de Venezuela, Caracas (R. Candia), MUSM, Museo de Historia Natural, Universidad Nacional Mayor de San Marcos, Lima (D. Silva); MZS, Museo Zoologico de "La Specola", Firenze (L. Bartolozzi); MZSP, Museu de Zoologia da Universidade de São Paulo, São Paulo (R. Pinto da Rocha); SMNK, Staatliches Museum für Naturkunde Karlsruhe, Karlsruhe (H. Höfer). All measurements are in millimeters. Morphological observations and illustrations were made using a Leica MZ12 stereomicroscope with camera lucida. Digital SEM photographs were taken on a JEOL (JSM 840A) scanning electron microscope from the Laboratório de Microscopia Eletrônica, Department de Física Geral, Instituto de Física, Universidade de São Paulo. The epigynum was detached from the abdomen and submerged in clove oil to clear the internal structures. Terminology follows, in part, SiLva (2003). Abbreviations: (aa) atrium aperture, (c) conductor, (cg) cymbial retrolateral groove, (d) dorsal, (e) embolus, (hp) hyaline projection, (ma) median apophysis, ( $\mathrm{mm}$ ) millimeter, (p) prolateral, (pe) posterior extension of the epigynal plate, (r) retrolateral, (s) spermathecae, (st) subtegulum, (v) ventral.

\section{RESULTS}

\section{Gephyroctenus Mello-Leitão, 1936}

Gephyroctenus Mello-Leitão, 1936: 26, pl. 2, fig. 49. Caporiacco, 1947; 1955: 398; Bonnet, 1957: 1992; Lehtinen, 1967: 235; Silva, 2003; Platnick, 2008.

Type species. Gephyroctenus philodromoides Mello-Leitão, 1936, by monotypy.

Revista Brasileira de Zoologia 25 (4): 705-715, December, 2008
Compositon. Nine species: Gephyroctenus philodromoides, G. portovelho sp. nov., G. juruti sp. nov., G. divisor sp. nov., G. panguana sp. nov., G. acre sp. nov., G. atininga sp. nov., G. esteio sp. nov. and G. mapia sp. nov.

Diagnosis. Gephyroctenus is distinguished from the remaining Calocteninae genera by the presence of a cymbial retrolateral groove (Fig. 8), retrolateral origin of embolus (Figs 7-8), embolus long and thin (Fig. 7), median apophysis with a subdistal hook (Fig. 9), and hyaline projection close to the embolus base (Fig. 7) in the male palp. The females are distinguished by the fused median and lateral fields in a single epigynal plate, copulatory opening located dorsally in an atrium (Fig. 13), and elongated copulatory ducts surrounding the spermathecae (Fig. 14) in the epigynum.

Description. Ecribelate ctenids. Total body length (males and females) 3.30-5.20. Carapace, chelicerae, labium, endites, sternum and legs pale brown; posterior median and lateral eyes on black tubercles; legs with dorsal transversal dark brown spots. Carapace flattened (Fig. 1). Eyes arranged in ctenoid pattern, 24-2. Labium short, wider than long. Fovea short, positioned in the posterior third of the carapace (Fig. 2). Legs I and II with a set of numerous and very long retrolateral and prolateral spines in the femur (Fig. 2) and ventral spines in the tibia (Fig. 3) and metatarsus. Trocanter slightly notched. Tarsal organ rounded and smooth, with drop shape aperture (Fig. 4). Trichobothrial base with 2 transversal grooves (Fig. 5). Abdomen subpentagonal (Fig. 2). Six erected bristels distally positioned in the anal tubercle (Fig. 2). Palp: tibia short, almost half cymbium length; RTA divided in ventral and dorsal branches (Fig. 7); cymbium with a retrolateral groove to accommodate the embolus (Fig. 8); tegulum rounded or oval, with median apophysis, conductor, embolus base and hyaline projection grouped retrolaterally (Fig. 7); median apophysis distally excavated, with a subdistal hook (Fig. 9); embolus long and thin, surronding the tegulum (Fig. 7), with a basal projection accomodated in a depression on the subtegulum (Fig. 8); conductor thin and hyaline, supporting the tip of the embolus (Fig. 9); hyaline projection close to the embolus base (Fig. 7), absent in G. juruti sp. nov. (Fig. 20); subtegulum positioned retrolaterally (Fig. 8). Epigynum: formed by a single plate, slightly sclerotized; the copulatory opening located dorsally in an atrium (Fig. 13); epiginal plate posteriorly extended to the dorsal area (Fig. 14); copulatory ducts surrounding the spermathecae and arrising ventrally at the anterior area of the spermathecae; fertilization ducts short, emerging from the posterior area of the spermathecae (Fig. 14).

Species allocation. The following synonymies are proposed for three species formerly included in Gephyroctenus. They are all based on the comparison of the type specimens, as listed below:

Gephyroctenus kolosvaryi Caporiacco, 1947 (immature holotype from Guyana, MZS, examined) is a junior synonym of Acanthoctenus spinipes Keyserling, 1877 (female holotype from Bogotá, Colombia, BMNH, examined). Syn. nov. 
Gephyroctenus parvus Caporiacco, 1947 (immature holotype from Guyana, MZS, examined) is junior synonym of Phymatoctenus comosus Simon, 1897 (female holotype from Brazil, MNHN, examined). Syn. nov.

Gephyroctenus vachoni Caporiacco 1955 (immature holotype and immature paratype from Caracas, Venezuela, 1948, Marcuzzi leg., MUCV 891 and 892 respectivelly, examined) is a junior synonym of Caloctenus gracilitarsis Simon, 1897 (2 female syntypes from Colonia Tovar, Aragua, Venezuela, MNHN 11025 and 2 females and an immature male syntypes from Caracas, Venezuela, MNHN 11118, examined). Syn. nov.

Natural history observations. An individual of Gephyroctenus philodromoides $(\mathrm{n}=1)$ was observed preying on ants of Azteca Forel, 1878 (Formicidae: Dolichoderinae) at night, next to the Rio Mapiá, Borba, State of Amazonas, Brazil. This behavior was also observed for G. mapia sp. nov. $(\mathrm{n}=2)$ at the same locality. Azteca ants are mutualistic with cases of association with myrmercophytic (plants that host ant colonies) species of Cecropia Loefl. (Cecropiaceae), known as Trumpet trees (FAVÉRI \& VASCONCELOS 2004). To prey the ants, the spider hangs itself in a branch of the Trumpet tree by the silk thread, positioned parallel to the stem. To capture the ants, the spider uses a pendulum movement, suspended by the silk thread of the spinnerets, probably helped by an auxiliary silk thread (not observed) (Fig. 41), catching a specimen using the first pair of legs, which are armed with a set of elongated spines (Fig. 3). After the capture, the spider eats the prey while still suspended by the silk thread.

Distribution. Amazonian and Atlantic forests in South America.

\section{Gephyroctenus philodromoides Mello-Leitão, 1936} Figs 1-14

Gephyroctenus philodromoides Mello-Leitão, 1936: 26, pl. 2, fig. 49 (immature holotype from Paranaguá, State of Paraná, Brazil, O. Leonardos leg., MNRJ 42310, examined). Bonnet, 1957: 1992; Lehtinen, 1967: 235; Silva, 2003; Platnick, 2008.

Note. The type specie was recognized by the type locality and the coloration of the abdomen.

Diagnosis. Gephyroctenus philodromoides is distinguished from the remaining species of the genus by the elongated dorsal branch of RTA (Fig. 10), median apophysis with elongated subdistal hook (Figs 10-11), and presence of a basal projection in the cymbial retrolateral groove (Fig. 12) in the male palp. Females are distinguished by the small sclerotized epigynal plate (Fig. 13), long and thin copulatory ducts, spermathecae smooth, and elongated and subquadrangular posterior extention of the epigynal plate (Fig. 14) in the epigynum.

Description. Male (IBSP 70300). Total length 5.00. Carapace 2.40 long, 2.20 wide. Clypeus 0.12 high. Eye diameter: AME 0.17, ALE 0.08, PME 0.10, PLE 0.12. Leg measurements: I: femur 3.10/patella 0.80/tibia 4.10/metatarsus 4.50/tarsus 1.30 / total 13.80; II: 3.10/0.80/3.30/3.70/1.00/11.90; III: 3.10/0.70/

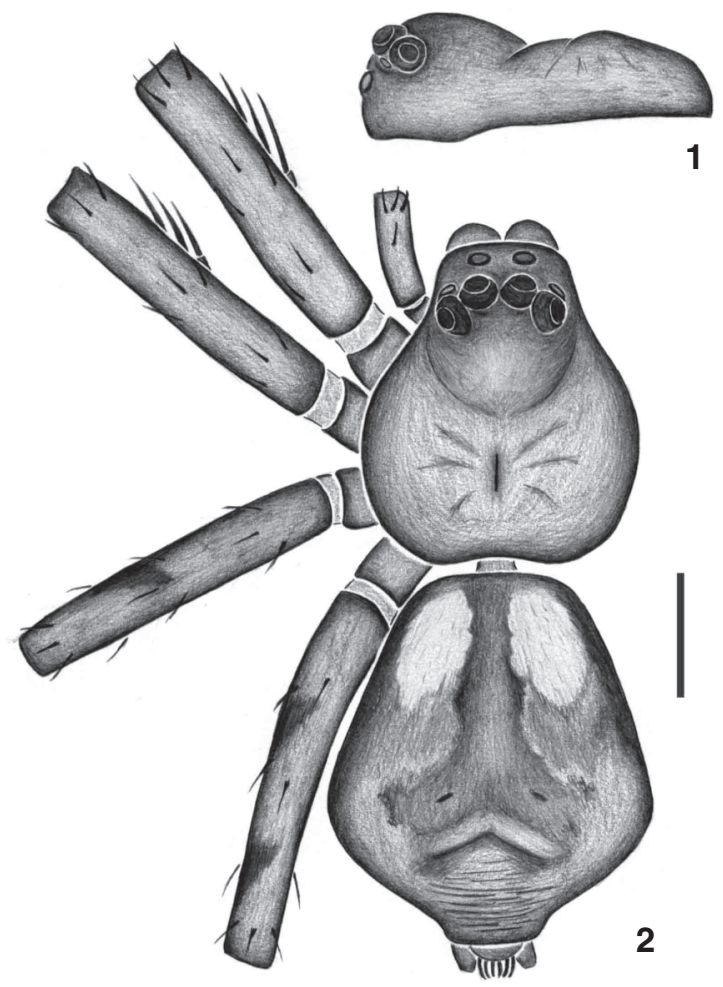

Figures 1-2. Gephyroctenus philodromoides: (1) carapace, lateral view; (2) dorsal view. Scale bar: $1.00 \mathrm{~mm}$.

2.80/3.90/1.10/11.60; IV: 3.90/0.70/3.40/5.50/1.50/15.00. Leg formula: 4123. Number of ventral pairs of spines: tibia I with 11; metatarsus I with 10; tibia and metatarsus II with 10 each. Abdomen light brown with two anterior paramedian white spots, two posterior paramedian dark brown spots and lateral areas dark brown (Fig. 2). Palp: deep cymbial retrolateral groove, with S-shape in dorsal view (Fig. 12); tegulum rounded (Fig. 10); subdistal hook of the median apophysis pointed at apex (Fig. 10); large and elongated hyaline projection close to the embolus base (Fig. 10).

Female (IBSP 70294). Total length 5.20. Carapace 2.10 long, 2.00 wide. Clypeus 0.18 high. Eye diameter: AME 0.16, ALE 0.08, PME 0.16, PLE 0.16. Leg measurements: I: femur 2.50/ patella 0.70 /tibia $2.70 /$ metatarsus 2.80 /tarsus $0.80 /$ total 9.50 ; II: 2.50/0.70/2.60/2.70/0.80/9.30; III: 2.70/0.70/2.30/3.20/0.90/ 9.80; IV: 3.20/0.70/2.60/4.20/1.10/11.80. Leg formula: 4312. Number of ventral pairs of spines: tibia I with 12 ; metatarsus I with 10; tibia II with 11; metatarsus II with 9. Abdomen coloration as in male. Epigynum: epigynal plate slightly sclerotized and wide atrium (Fig. 13).

Variation. 10 males: total length 4.80-5.00, carapace 2.402.50, femur I 3.50-3.90; 10 females: total 5.00-5.60, carapace 2.20-2.30, femur I 2.50-2.70.

Additional material examined. Peru, Loreto: Rio Samiria, 

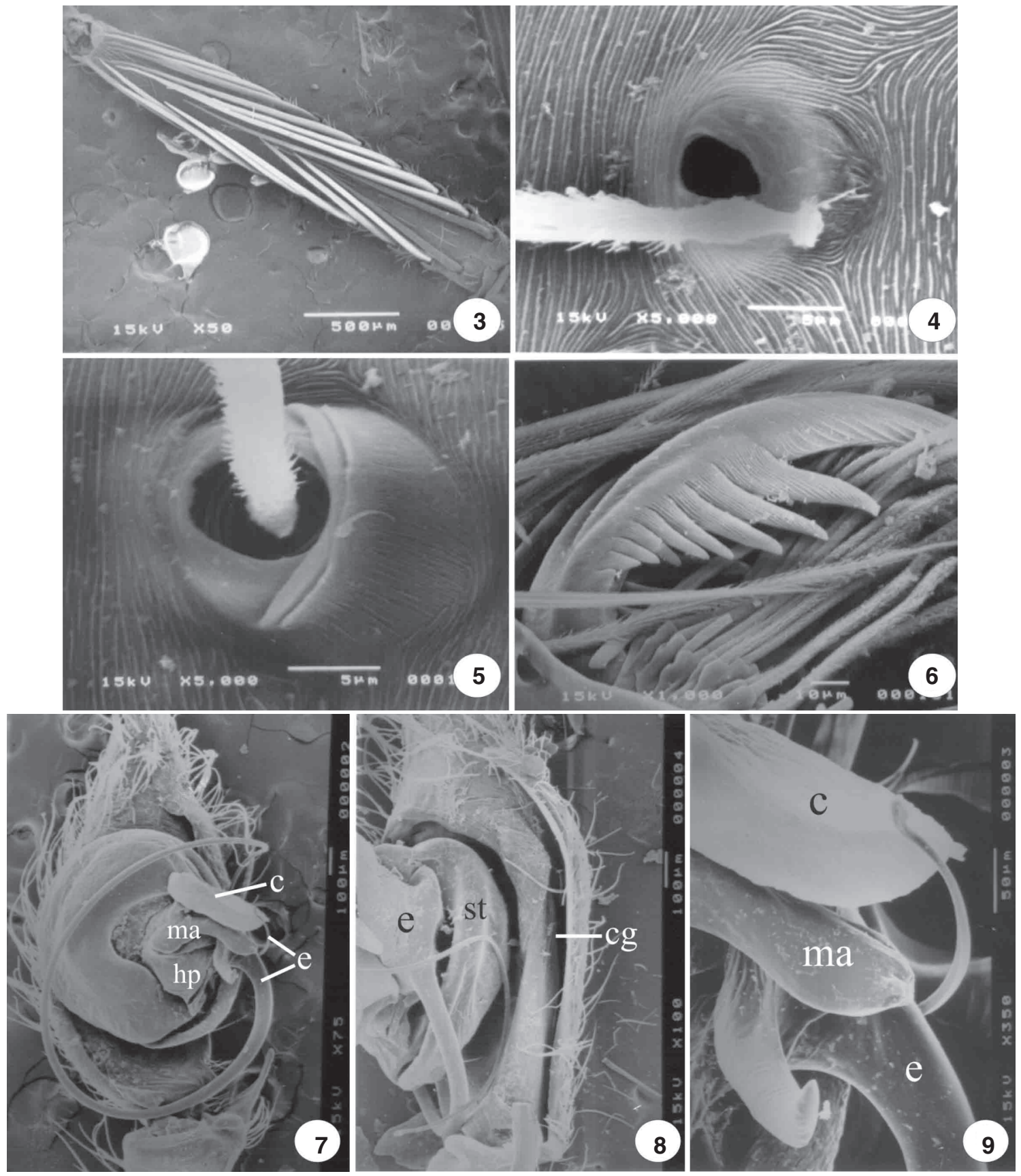

Figures 3-9. Gephyroctenus philodromoides: (3) tibia I, ventral view; (4) tarsal organ; (5) trichobothrium; (6) male tarsal claw, leg l; (7-9) male left palp: (7) ventral view; (8) retrolateral view; (9) details of conductor, median apophysis and embolus tip. (c) Conductor, (cg) cymbial retrolateral groove, (e) embolus, (hp) hyaline projection, (ma) median apophysis, (st) subtegulum.

1 male, 1 female, 2 immatures, V.1990, T. Erwin leg. (MUSM). BRAzIL, Amazonas: Manaus (Reserva Florestal Adolpho Ducke), 1 female, 1991 (INPA); 1 female, 1992 (IBSP 91137); 1 male, 1992 (INPA); 1 female, 1992 (SMNK) all A.D. Brescovit leg.; 22 males, 1 female, 1992 (INPA); 4 males, 1993 (INPA); 1 male, 1991 (SMNK); 22 males, 3 females, 1992 (SMNK); 9 males, 6 females, 1992 (IBSP 91133, 91136, 91143, 91144-91146, 91149, 91159); 1 male, 18.I.1993 (IBSP 91154); 10 males, 2 females,

Revista Brasileira de Zoologia 25 (4): 705-715, December, 2008 

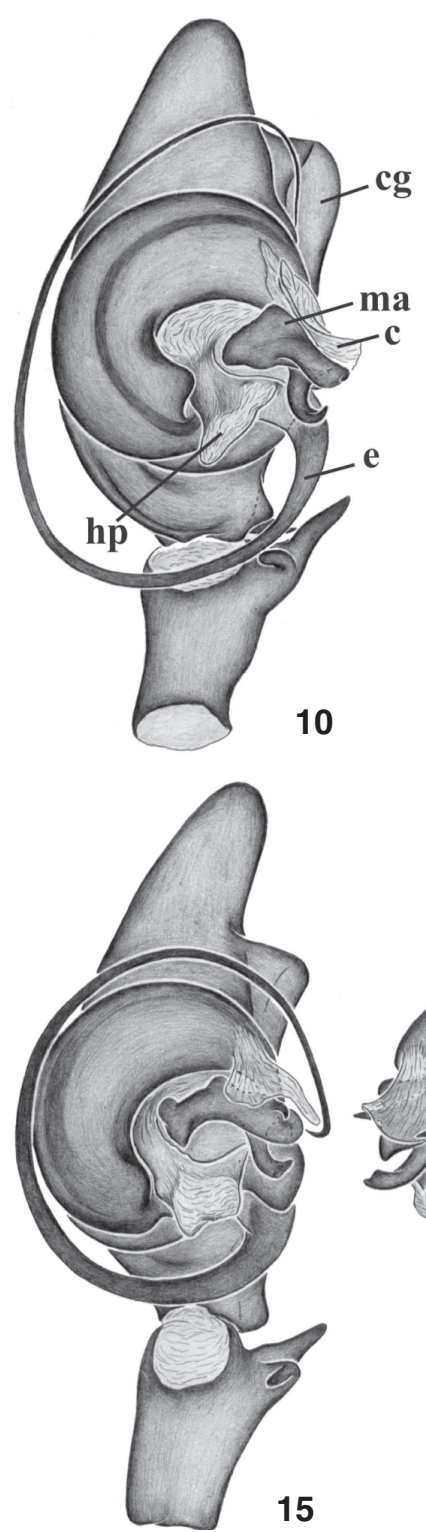
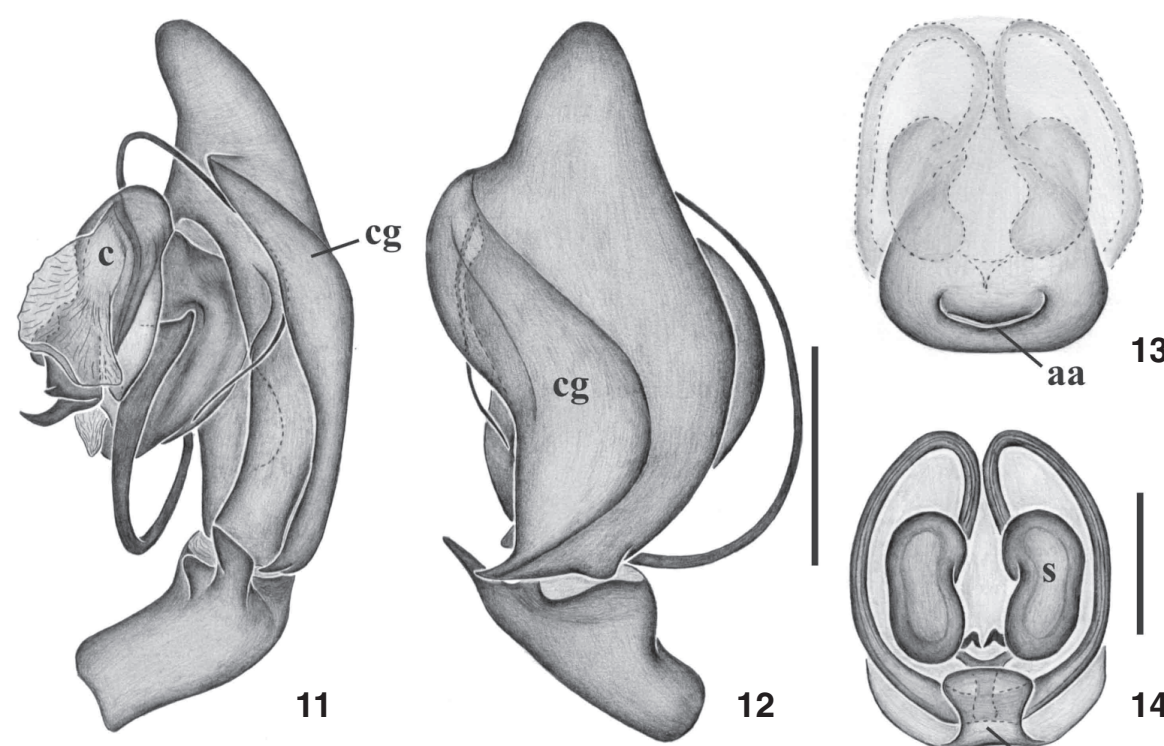

13
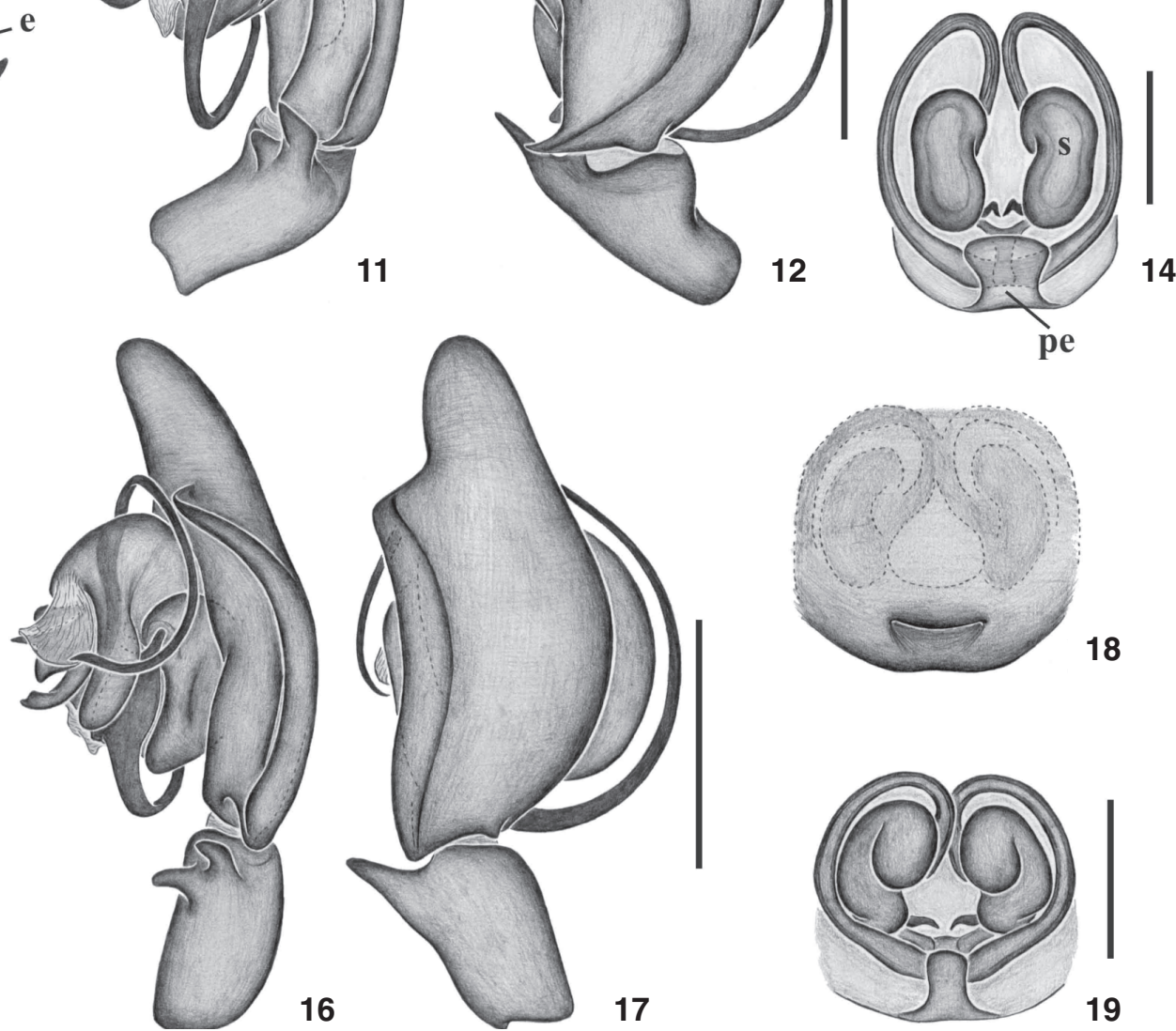

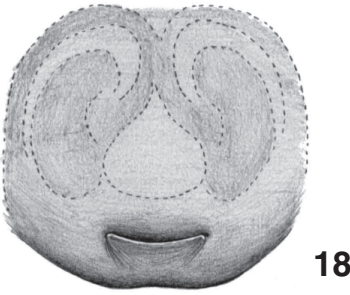

18

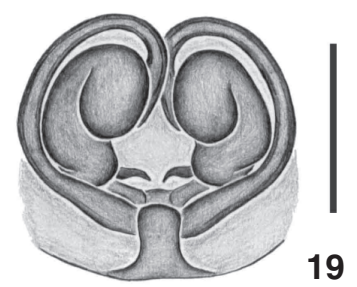

Figures 10-19. Gephyroctenus philodromoides. (10-12)male left palp: (10) ventral view; (11) retrolateral view; (12) dorsal view. Scale bar 0.50 mm; (13-14) epigynum: (13) ventral view; (14) dorsal view; (15-19) Gephyroctenus portovelho sp. nov.: (15-17) male left palp: (15) ventral view; (16) retrolateral view; (17) dorsal view; (18-19) epigynum: (18) ventral view; (19) dorsal view. Scale bar $0.25 \mathrm{~mm}$. (aa) Atrium aperture, (c) conductor (cg) cymbial retrolateral groove, (e) embolus, (hp) hyaline projection, (ma) median apophysis, (pe) posterior extension of the epigynal plate, (s) spermathecae.

1991 (IBSP 91138, 91150, 91169, 91171-91174) all H. Höfer \& T. Gasnier leg.; 3 males, 1993, J. Vidal leg. (IBSP 91131); (Fazenda Esteio), 3 males, 1 female, 1985 (IBSP 91140-91142); 5 males, 1985 (MCN 19740, 19844, 19882); 1 male, 1986 (MCN 19772), all B.C. Klein leg.; 1 male, 1995, L. Silva leg. (IBSP 7070); (Reserva do Km 41), 2 males, VIII.2000, A.J. Santos leg. (IBSP 37234, 37243). Coari (Rio Urucú, Porto Urucú), 5 males, 1 female, 21-
24.VII.2003, A.B. Bonaldo leg. (MPEG 699-701, 1784, 1785); 1 male, 1 female, 23.VII.2003, A.B. Bonaldo leg. (IBSP 91166); 1 female, 19.VII.2003, D.D. Guimarães leg. (MPEG 1783); Manicoré (Rio Atininga), 1 male, 19.IV.1996. IBSP/SMNK leg. (IBSP 62954). Pará: Tucuruí (Rio Tocantins), 1 male, 518.XII.1985, N. Degallier leg. (MPEG 3449). Bahia: Una (Reserva Biológica do Una), 17 males, 4 females, 15-28.XI.2000, A.D. 
Brescovit et al. leg. (IBSP 18214, 45018, 45025-45035, 47193, 48286, 48296). São Paulo: Ubatuba (Fazenda Angelim), 2 males, 17-19.XII.2003, C. Rheims \& R. Indicatti leg. (IBSP 52264); Iporanga (Parque Estadual Turístico do Alto Ribeira, 24 $32^{\prime} \mathrm{S}$ $48^{\circ} 41^{\prime} \mathrm{W}$ ), 33 males, 15 females, 8-15.XI.2001 (IBSP 70287 70310); 8-15.XI.2001, 1 male, 1 female (MZSP); 8-15.XI.2001, 1 male, 1 female (MPEG), all Equipe Biota leg. Paraná: Antonina, 1 male, 1 female, 2.III.1987, PROFAUPAR/CIIF leg. (IBSP 70313, 70314). Santa Catarina: Blumenau (Parque Natural Municipal Nascentes do Ribeirão Garcia), 2 females, 21-28.I.2003, Equipe Biota leg. (IBSP 88301, 88302); Paulo Lopes (Parque Estadual do Tabuleiro), 1 male, 10 females, 10-20.I.2002, Equipe Biota leg. (IBSP 88304-88311).

Distribution. Department of Loreto, Peru and States of Amazonas, Bahia, São Paulo, and Paraná, Brazil.

\section{Gephyroctenus portovelho sp. nov.}

\section{Figs 15-19}

Type material. Male holotype and female paratype from Brazil, Rondônia: Porto Velho, 15.IV.1996, IBSP/SMNK leg., deposited in IBSP 62950; female paratype from BrazIL, Amazonas: Manaus, Fazenda Esteio, no date, B. C. Klein leg., deposited in IBSP 62953; male and female paratypes from BrazIL, Amazonas: São Gabriel da Cachoeira, Cachoeira do Tucano, Pico da Neblina, IX.2007, A. Nogueira leg., deposited in INPA.

Diagnosis. Gephyroctenus portovelho sp. nov. is distinguished from the remaining species of the genus by the median apophysis with subdistal hook truncated and cymbial retrolateral groove shallow (Figs 15 and 16) in the male palp. Females are distinguished by the epigynal plate wide and slightly excavated posteriorly, large and slightly curved atrium, and elongated posterior extention of the epigynal plate (Fig. 18) in the epigynum.

Description. Male (IBSP 62950). Total length 3.80. Carapace 1.80 long, 1.60 wide. Clypeus 0.12 high. Eye diameter: AME 0.17, ALE 0.08, PME 0.16, PLE 0.16. Leg measurements: I: femur 2.70/patella 0.70/tibia 3.40/metatarsus 3.70/tarsus $1.00 /$ total 11.50; II: 2.40/0.70/2.80/3.20/0.90/10.00; III: 2.50/0.60/ 2.50/3.30/0.90/9.80; IV: 2.90/0.50/2.80/4.10/1.10/11.40. Leg formula: 1423. Number of ventral pairs of spines: tibia and metatarsus I with 10 each; tibia II with 10; metatarsus II with 9. Abdomen coloration as in G. philodromoides. Palp: tegulum rounded and hyaline projection short and truncated close to the embolus base (Fig. 15).

Female (IBSP 62950). Total length 4.10. Carapace 1.70 long, 1.50 wide. Clypeus 0.14 high. Eye diameter: AME 0.12, ALE 0.08, PME 0.12, PLE 0.12. Leg measurements: I: femur 2.00/ patella 0.60 /tibia 2.20 /metatarsus 2.10 /tarsus 0.60 /total 7.50 ; II: 1.90/0.60/1.90/1.90/0.60/6.90; III: 1.90/0.50/1.50/2.00/0.70/ 6.60; IV: 2.10/0.50/1.70/2.70/0.90/7.90. Leg formula: 4123 . Number of ventral pairs of spines: tibia and metatarsus I with 9 each; tibia II with 9; metatarsus II with 8. Abdomen coloration as in $G$. philodromoides. Epigynum: spermathecae with anterior area dorsally curved and laterally projected (Fig. 19). Variation. Two females: total 4.10-4.30, carapace 1.70 1.90, femur I 2.00-2.10.

Additional material examined. BraziL, Amazonas: São Gabriel da Cachoeira, (Cachoeira do Tucano, Pico da Neblina), 1 male, 1 female, IX.2007, A. Nogueira leg. (IBSP 90500, 90501). Distribution. States of Rondônia and Amazonas, Brazil. Etymology. The specific epithet is a toponym in apposition.

\section{Gephyroctenus juruti sp. nov. Figs 20-24}

Type material. Male holotype and female paratype from Brazil, Pará: Juruti (Igarapé Mutum, Platô do Rio Juruti), 12.IX.2002, A.B. Bonaldo leg., deposited in MPEG 394; male paratype with same data as holotype, deposited in IBSP 70872; female paratype from same locallity as holotype, deposited in IBSP 70873; male and female paratype from PERU, Loreto: Rio Samiria, V.1990, T. Erwin leg., deposited in MUSM.

Diagnosis. Gephyroctenus juruti sp. nov. is distinguished from the remaining species of the genus by the dorsal branch of RTA short (Fig. 21), median apophysis with subdistal hook thin and elongated (Figs 20 and 21), and absence of the hyaline projection close to the embolus base (Fig. 20) in the male palp. Females are distinguished by the truncated and posteriorly projected epigynal plate (Fig. 23), atrium with a large and straight aperture (Fig. 23), short posterior extention of the epigynal plate, and spermathecae with two dorsal folds in the epigynum (Fig. 24).

Description. Male (holotype). Total length 3.60. Carapace 1.80 long, 1.60 wide. Clypeus 0.12 high. Eye diameter: AME 0.14, ALE 0.08, PME 0.12, PLE 0.12. Leg measurements: I: femur 2.80 /patella 0.60 /tibia 2.90 /metatarsus $3.10 /$ tarsus $1.00 /$ total 10.40; II: $2.50 / 0.60 / 2.70 / 2.90 / 1.00 / 9.70$; III: $2.40 / 0.50 /$ 2.20/2.90/1.00/9.00; IV: 3.00/0.50/2.70/4.00/1.30/11.50. Leg formula: 4123. Number of ventral pairs of spines: tibia I with 10; metatarsus I with 9; tibia II with 9; metatarsus II with 8. Abdomen coloration as in G. philodromoides. Palp: tibia with two prolateral spines (Fig. 20), cymbial retrolateral groove shallow (Fig. 22), tegulum rounded and median apophysis distally truncated (Figs 20 and 21).

Female (Paratype MPEG 394). Total length 4.30. Carapace 1.75 long, 1.45 wide. Clypeus 0.14 high. Eye diameter: AME 0.12, ALE 0.08, PME 0.12, PLE 0.12. Leg measurements: I: femur 2.10 /patella 0.50 /tibia 2.20 /metatarsus 2.10 /tarsus 0.60 / total 7.50; II: 2.00/0.50/1.90/1.90/0.60/6.90; III: 1.70/0.60/1.60/ 1.80/0.70/6.40; IV: 2.30/0.60/1.90/2.70/0.80/8.30. Leg formula: 4123. Number of ventral pairs of spines: tibia I with 10 ; metatarsus I with 9; tibia II with 9; metatarsus II with 8. Abdomen coloration as in G. philodromoides. Epigynum: large and straight atrium (Fig. 23) and large spermathecae (Fig. 24).

Variation. Three males: total 3.60-3.70, carapace 1.801.85, femur 2.80-2.90. Five females: total 4.30-4.50, carapace 

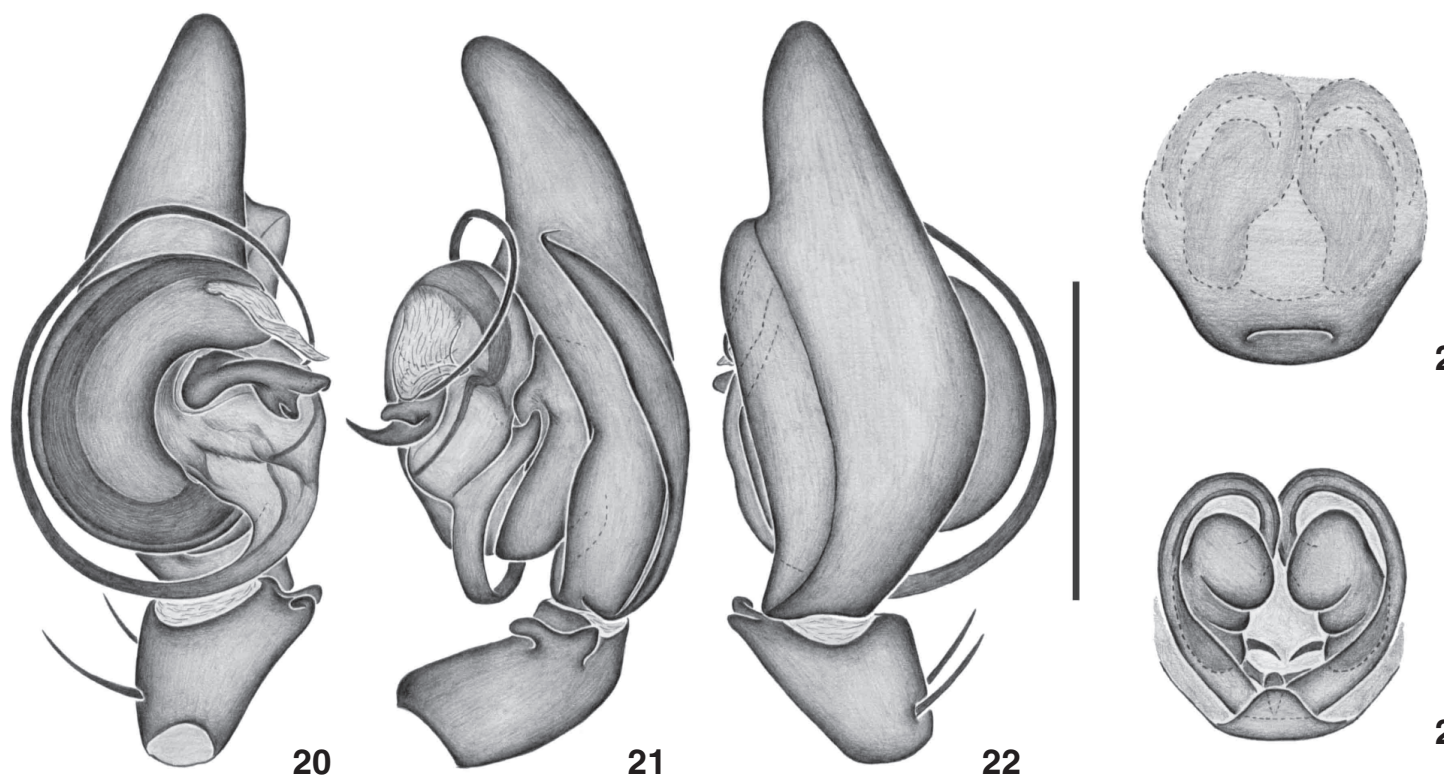

23
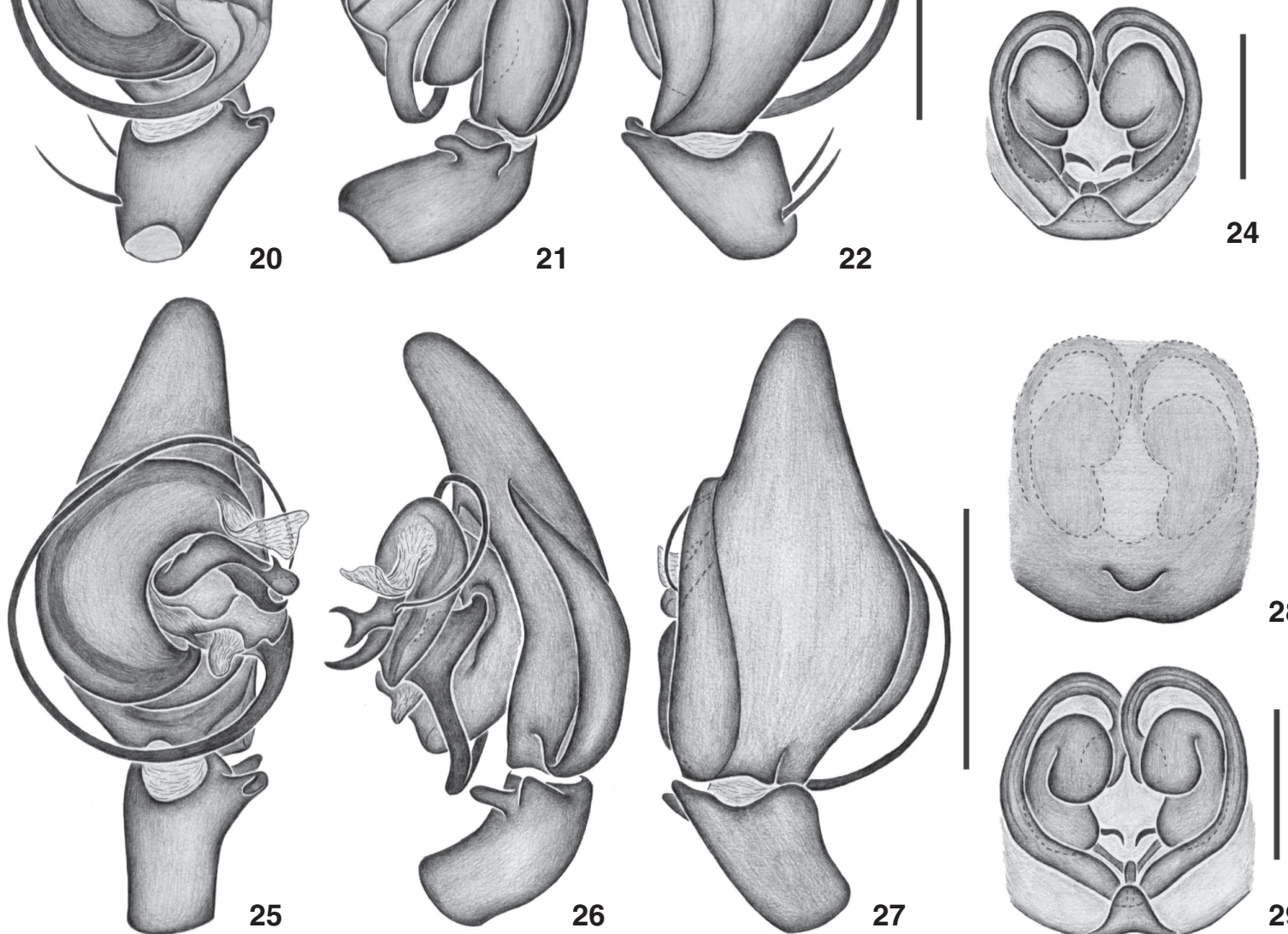

28

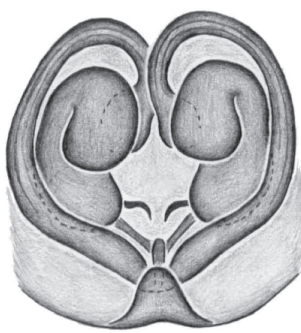

Figures 20-29. (20-24) Gephyroctenus juruti sp. nov.: (20-22) male left palp: (20) ventral view; (21) retrolateral view; (22) dorsal view; (2324) epigynum: (23) ventral view; (24) dorsal view; (25-29) Gephyroctenus divisor sp. nov.: (25-27) male left palp: (25) ventral view; (26) retrolateral view; (27) dorsal view; (28-29) epigynum: (28) ventral view; (29) dorsal view. Scale bars: epigyum =0.25 mm; palp=0.50 mm.

\subsection{0-1.75, femur I 2.10-2.20.}

Additional material examined. BrazıL, Pará: Juruti, 1 male, 3 females (MPEG 1762, 11369, 11387, 11388); Igarapé Mutum (Platô do Rio Juruti), 1 female, 9.IX.2002, A.B. Bonaldo leg. (MPEG 393).

Distribution. Department of Loreto, Peru and State of Pará, Brazil.

Etymology. The species epithet is a toponymy in apposition.

\section{Gephyroctenus divisor sp. nov.}

Figs 25-29

Type material. Male holotype from BraziL, Acre: Cruzeiro do Sul (Parque Nacional da Serra do Divisor), 25.III.1997, L. Resende \& R. S. Vieira leg., deposited in IBSP 12188; female paratype from the same locality as holotype, 24.XI.1996, R. S. Vieira leg., deposited in IBSP 9043.

Note. The criterion used to match males and females of

Revista Brasileira de Zoologia 25 (4): 705-715, December, 2008 
this species was the similarity of the abdomen coloration. A second female morphospecies was collected in the same area, but it is described as Gephyroctenus acre sp. nov. in this paper.

Diagnosis. Gephyroctenus divisor sp. nov. is distinguished from the remaining species of the genus by the median apophysis with elongated base (Fig. 25) and short hyaline projection close to the embolus base (Fig. 25) in the male palp. Females are distinguished by the atrium with curved aperture (Fig. 28), thin posterior extention of the epigynal plate, and spermathecae with anterior area dorsally curved (Fig. 29) in the epigynum.

Description. Male (IBSP 12188). Total length 3.30. Carapace 1.80 long, 1.60 wide. Clypeus 0.12 high. Eye diameter: AME 0.14, ALE 0.08, PME 0.14, PLE 0.14. Leg measurements: I: femur 2.60/patella 0.60/tibia 2.70/metatarsus 3.00/tarsus $1.00 /$ total 9.90; II: 2.60/0.60/2.80/3.10/1.00/10.10; III: 2.50/0.50/ 2.40/2.90/0.90/9.20; IV: 3.20/0.60/2.70/4.10/1.20/11.80. Leg formula: 4213. Number of ventral pairs of spines: tibia I with 9; metatarsus I with 8; tibia II with 9; metatarsus II with 7. Abdomen light brown with a longitudinal brown stripe, lateral areas dark brown and posterior area white. Palp: cymbial retrolateral groove shallow (Fig. 27), tegulum rounded and subdistal hook of median apophysis pointed at apex (Figs 25 and 26).

Female (IBSP 9043). Total length 3.50. Carapace 1.60 long, 1.40 wide. Clypeus 0.10 high. Eye diameter: AME 0.12, ALE 0.08, PME 0.12, PLE 0.12. Leg measurements: I: femur 1.80/ patella $0.60 /$ tibia 2.00 /metatarsus 1.90 /tarsus $0.50 /$ total 6.80 ; II: 1.80/0.60/1.70/1.80/0.50/6.40; III: 1.70/0.50/1.40/1.80/0.60/ 6.00; IV: 2.10/0.50/1.70/2.50/0.80/7.60. Leg formula: 4123 . Number of ventral pairs of spines: tibia I with 10; metatarsus I with 9; tibia and metatarsus II with 9 each. Abdomen coloration as in male. Epigynum: epigynal plate large and slightly projected posteriorly (Fig. 28) and large spermathecae (Fig. 29).

Distribution. State of Acre, Brazil.

Etymology. The species epithet is a toponymy in apposition.

\section{Gephyroctenus panguana sp. nov.}

Figs 30-32

Type material. Male holotype from Peru, Huanuco: Puerto Inca (Estación Biológica Panguana), 1998, C. Manhart leg., deposited in MCN 19401.

Diagnosis. Gephyroctenus panguana sp. nov. is distinguished from the remaining species of the genus by the oval tegulum (Fig. 30) and the median apophysis with large and truncated subdistal hook (Figs 30 and 31) in the male palp.

Description. Male (MCN 19401). Total length 3.40. Carapace 1.70 long, 1.50 wide. Clypeus 0.10 high. Eye diameter: AME 0.14, ALE 0.08, PME 0.14, PLE 0.14. Leg measurements: I: femur 2.60/patella 0.70/tibia 2.90/metatarsus $2.90 /$ tarsus $1.10 /$ total 10.20; II: 2.40/0.70/2.70/2.80/0.90/9.50; III: 2.40/0.50/ 2.20/2.80/0.80/8.70; IV: 3.00/0.50/2.60/3.80/1.00/10.90. Leg formula: 4123. Number of ventral pairs of spines: tibia I with 10; metatarsus I with 9; tibia II with 10; metatarsus II with 9. Abdomen light brow with two anterior paramedian white spots and posterior area white. Palp: cymbial retrolateral groove large (Fig. 32) and hyaline projection short and truncated close to the embolus base (Fig. 30).

Female. Unknown.

Distribution. Department of Huanuco, Peru.

Etymology. The species epithet is a toponymy in apposition.

\section{Gephyroctenus acre sp. nov.}

\section{Figs 33-34}

Type material. Female holotype from BRAzIL, Acre: Cruzeiro do Sul (Parque Nacional da Serra do Divisor), 5-25.XI.1996, R. S. Vieira et al. leg., deposited in IBSP 9249.

Diagnosis. Gephyroctenus acre sp. nov. is distinguished from the remaining females of the genus by the atrium with a large aperture with anterior projection (Fig. 33) and large and rounded posterior extention of the epigynal plate (Fig. 34) in the epigynum.

Description. Male. Unknown.

Female (holotype). Total length 3.90. Carapace: 1.80 long, 1.60 wide. Clypeus 0.11 high. Eye diameter: AME 0.12, ALE 0.08, PME 0.12, PLE 0.12. Leg measurements: I: absent; II: absent; III: femur 2.10; IV: femur 2.50. Abdomen coloration: as in G. philodromoides. Epigynum: epigynal plate truncated posteriorly (Fig. 33) and smooth spermathecae (Fig. 34).

Distribution. State of Acre, Brazil.

Etymology. The species epithet is a toponymy in apposition.

\section{Gephyroctenus atininga sp. nov.}

\section{Figs 35-36}

Type material. Female holotype from BrazIL, Amazonas: Manicoré (Rio Atininga), 19.IV.1996, IBSP/SMNK leg., deposited in IBSP 62952.

Diagnosis. Gephyroctenus atininga sp. nov. is distinguished from the remaining females of the genus by the atrium with a large and slightly curved aperture (Fig. 35), wide posterior extention of the epigynal plate and the large spermathecae (Fig. 36) in the epigynum.

Description. Male. Unknown.

Female (holotype). Total length 4.00. Carapace: 1.90 long, 1.70 wide. Clypeus 0.16 high. Eye diameter: AME 0.14, ALE 0.08, PME 0.14, PLE 0.14. Leg measurements: I: absent; II: femur 2.20/patella 0.60 /tibia $2.00 /$ metatarsus 2.20 /tarsus 0.60 / total 7.60; III: 2.20/0.50/1.90/2.50/0.70/7.80; IV: 2.50/0.50/ 2.00/3.20/0.90/9.10. Number of ventral pairs of spines: tibia II with 10; metatarsus II with 9. Abdomen coloration: as in $G$. philodromoides. Epigynum: epigynal plate large and rounded posteriorly (Fig. 35). 

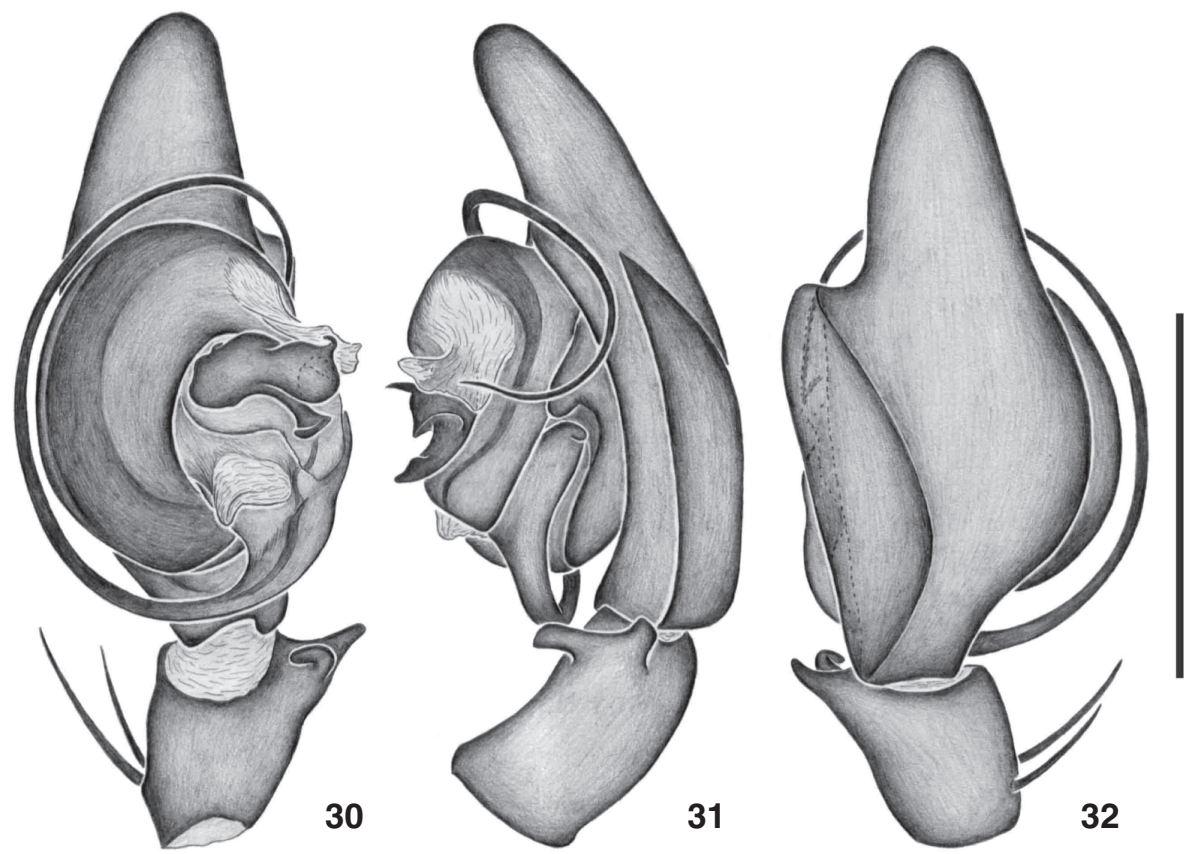

Figures 30-32. Gephyroctenus panguana sp. nov., male left palp: (30) ventral view; (31) retrolateral view; (32) dorsal view. Scale bars: epigyum $=0.25 \mathrm{~mm} ;$ palp $=0.50 \mathrm{~mm}$.
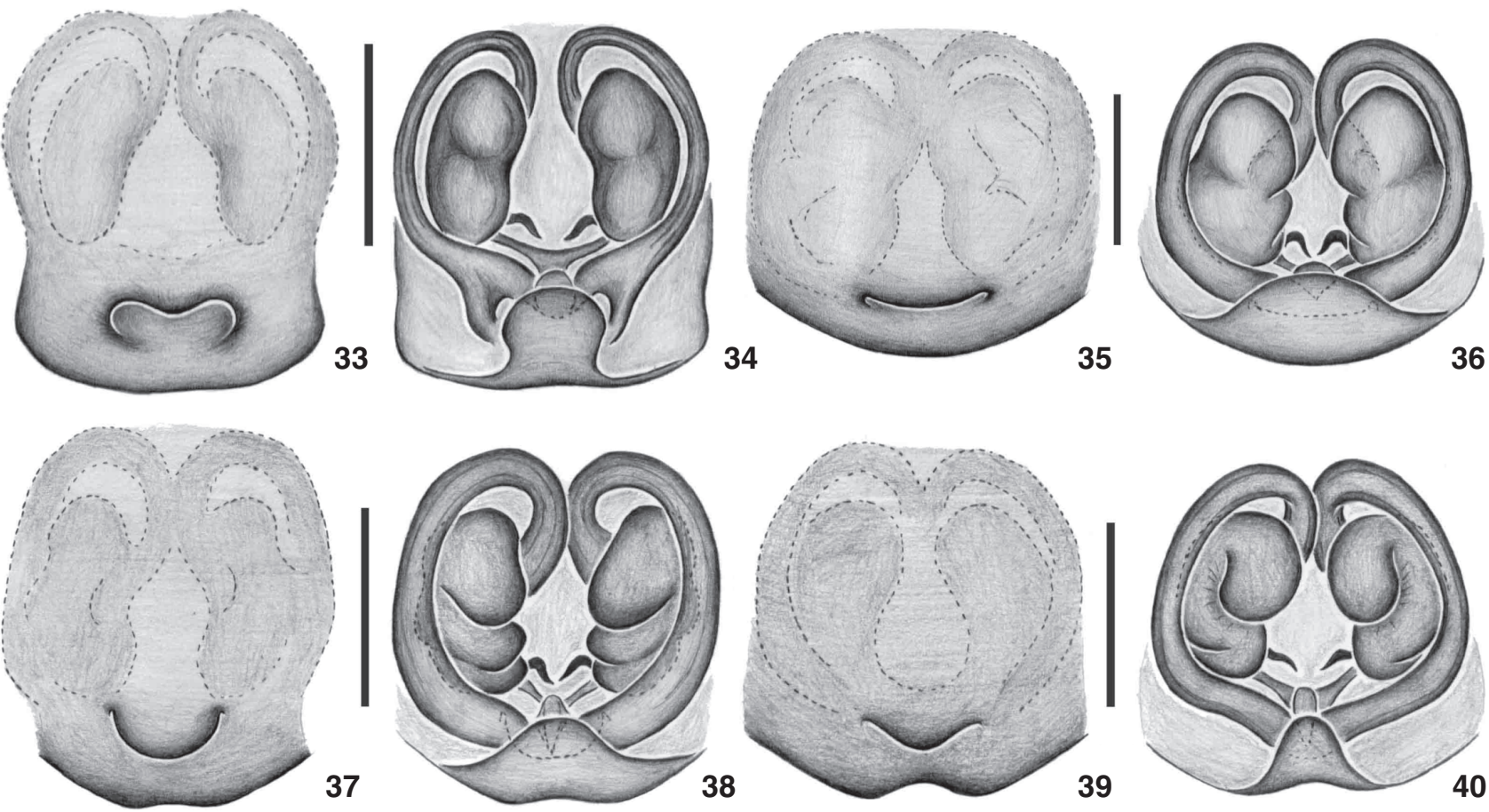

Figures 33-40. Epigynum. (33-34) G. acre sp. nov.: (33) ventral view; (34) dorsal view; (35-36) G. atininga sp. nov.: (35) ventral view; (36) dorsal view; (37-38) G. esteio sp. nov.: (37) ventral view; (38) dorsal view; (39-40) G. mapia sp. nov.: (39) ventral view; (40) dorsal view. Scale bar $0.25 \mathrm{~mm}$. 
Distribution. State of Amazonas, Brazil.

Etymology. The species epithet is a toponymy in apposition.

\section{Gephyroctenus esteio sp. nov. \\ Figs 37-38}

Type material. Female holotype from BRAzIL, Amazonas: Manaus (Fazenda Esteio), B. C. Klein leg., deposited in IBSP 62953.

Diagnosis. Gephyroctenus esteio sp. nov. is distinguished from the remaining females of the genus by the atrium with a strongly curved aperture (Fig. 37), wide posterior extention of the epigynal plate, and by the large spermathecae with two dorsal folds (Fig. 38) in the epigynum.

Description. Male. Unknown.

Female (holotype). Total length 4.20. Carapace: 1.70 long, 1.50 wide. Clypeus 0.16 high. Eye diameter: AME 0.12, ALE 0.08, PME 0.12, PLE 0.12. Leg measurements: I: femur 2.00/ patella 0.70 /tibia 2.20 /metatarsus 2.20 /tarsus $0.60 /$ total 7.70 ; II: 1.90/0.70/2.00/2.10/0.60/7.30; III: 1.90/0.50/1.70/2.10/0.70/ 6.90; IV: 2.30/0.50/2.00/2.70/0.80/8.30. Leg formula: 4123 . Number of ventral pairs of spines: tibia I with 10; metatarsus I with 9; tibia and metatarsus II with 9 each. Abdomen coloration: as in G. philodromoides. Epigynum: epigynal plate narrow and slightly projected posteriorly (Fig. 37).

Distribution. State of Amazonas, Brazil.

Etymology. The species epithet is a toponymy in apposition.

\section{Gephyroctenus mapia sp.nov.}

Figs $39-40$

Type material. Female holotype and female paratype from Brazil, Amazonas: Borba (Rio Mapiá), 22.IV.1996, IBSP/SMNK leg., deposited in IBSP 62951.

Diagnosis. Gephyroctenus mapia sp. nov. is distinguished from the remaining females of the genus by the atrium with curved aperture (Fig. 39), elongated posterior extention of the epigynal plate, and spermathecae with anterior area dorsally curved and laterally projected (Fig. 40) in the epigynum.

Description. Male. Unknown.

Female (holotype). Total length 4.30. Carapace: 1.90 long, 1.60 wide. Clypeus 0.16 high. Eye diameter: AME 0.14, ALE 0.08, PME 0.14, PLE 0.14. Leg measurements: I: femur 2.20/ patella $0.60 /$ tibia 2.50 /metatarsus 2.40 /tarsus $0.60 /$ total 8.30 ; II: 2.10/0.60/2.20/2.20/0.60/7.70; III: 2.10/0.50/1.80/2.30/0.70/ 7.50; IV: 2.40/0.50/2.00/3.20/0.80/8.90. Leg formula: 4123 . Number of ventral pairs of spines: tibia I with 10; metatarsus I with 9; tibia and metatarsus II with 9 each. Abdomen coloration: as in G. philodromoides. Epigynum: epigynal plate large and medianly depressed (Fig. 39).

Distribution. State of Amazonas, Brazil. tion.

Etymology. The species epithet is a toponymy in apposi-

Revista Brasileira de Zoologia 25 (4): 705-715, December, 2008

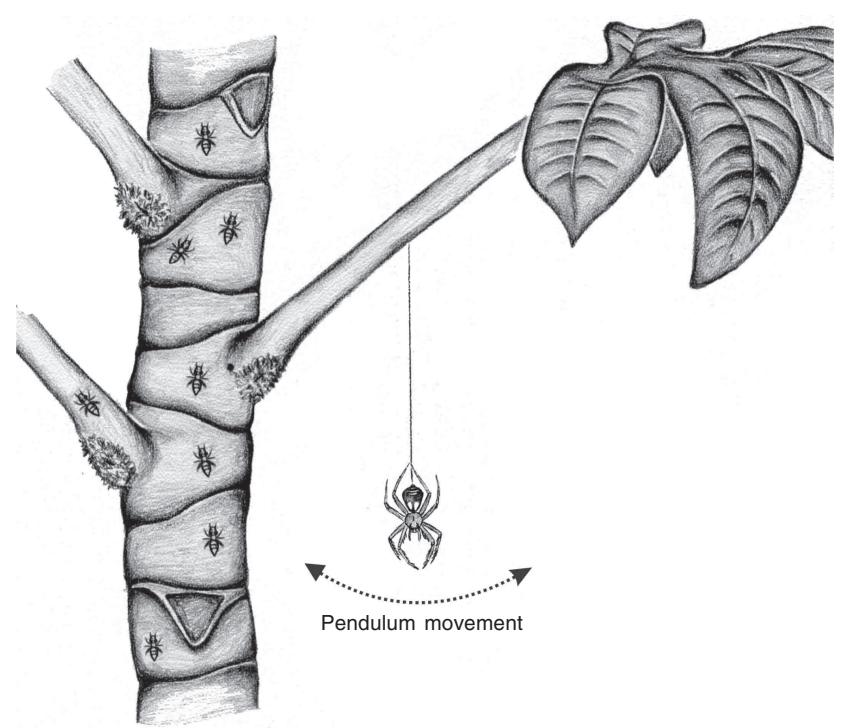

Figure 41. Scheme of the hunting behavior of $G$. philodromoides and G. mapia sp. nov. on a Cecropia tree.

\section{ACKNOWLEDGMENTS}

We are grateful to Cristina A. Rheims and Glauco Machado for helpful suggestions on the manuscript. We also thank Rodrigo M. Feitosa from the Museu de Zoologia, São Paulo, for the identification of the ants. This study was supported by CNPq and FAPESP (grant numbers 99/05446-8 and 06/55230-7). This study is part of the doctor degree of the first author in Instituto de Biociências of the Universidade de São Paulo and BIOTA/ FAPESP - The Biodiversity Virtual Institute Program (www.bio tasp.org.br).

\section{LITERATURE CITED}

Bonnet, P. 1957. Bibliographia araneorum. Toulouse 2 (3): 1927-3026.

CAPORIACCO, L. DI. 1947. Diagnosi preliminari de specie nuove di aracnidi della Guiana Brittanica raccolte dai professori Beccari e Romiti. Monitore Zoologico Italiano 56: 20-34.

Caporiacco, L. DI. 1955. Estudios sobre los aracnidos de Venezuela. 2a parte: Araneae. Acta Biologica Venezuelana 1: 265-448.

Fáveri, S.B. \& H.L. Vasconcelos. 2004. The Azteca-Cecropia association: are ants always necessary for their host plants? Biotropica 36 (4): 641-646.

Lehtinen, P.T. 1967. Classification of the Cribellate spiders and some allied families, with notes on the evolution of the suborder Araneomorpha. Annales Zologici Fennici 4 (3): 199-468.

Mello-Leitão, C.F. DE. 1936. Contribution à l'etude des Ctenides du Bresil. Festschrift für Strand 1: 1-31.

Platnick, N.I. 2008. The world spider catalog, version 8.5. 
American Museum of Natural History. Available online at: http://research.amnh.org/entomology/spiders/catalog/ index.html [Accessed: 10/I/2008].

SILVA, D. 2003. Higher-level relationships of the spider family
Ctenidae (Araneae: Ctenoidea). Bulletin of the American Museum of Natural History 274: 1-86.

SimON, E. 1897. Histoire naturelle des araignées. Paris, vol. 2, p. 1-192.

Submitted: 10.III.2008; Accepted: 24.XI.2008.

Editorial responsibility: Gabriel L.F. Mejdalani 